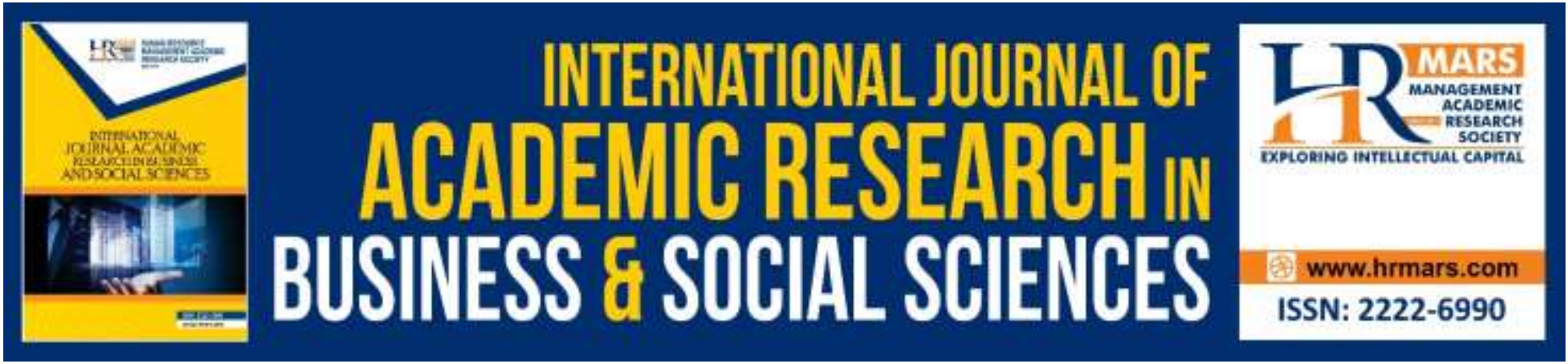

\title{
Inclusive Development for B40 Households Group: Malaysian Reality in Achieving Developed Nation Status by 2025
}

Radieah Mohd Nor

To Link this Article: http://dx.doi.org/10.6007/IJARBSS/v9-i7/6208

DOI: $10.6007 /$ IJARBSS/v9-i7/6208

Received: 06 May 2019, Revised: 12 June 2019, Accepted: 29 June 2019

Published Online: 09 July 2019

In-Text Citation: (Nor, 2019)

To Cite this Article: Nor, R. M. (2019). Inclusive Development for B40 Households Group: Malaysian Reality in Achieving Developed Nation Status by 2025. International Journal of Academic Research in Business and Social Sciences, 9(7), 1035-1048.

Copyright: (C) 2019 The Author(s)

Published by Human Resource Management Academic Research Society (www.hrmars.com)

This article is published under the Creative Commons Attribution (CC BY 4.0) license. Anyone may reproduce, distribute, translate and create derivative works of this article (for both commercial and non-commercial purposes), subject to full attribution to the original publication and authors. The full terms of this license may be seen at: http://creativecommons.org/licences/by/4.0/legalcode

\section{Vol. 9, No. 7, 2019, Pg. 1035 - 1048}

Full Terms \& Conditions of access and use can be found at http://hrmars.com/index.php/pages/detail/publication-ethics 


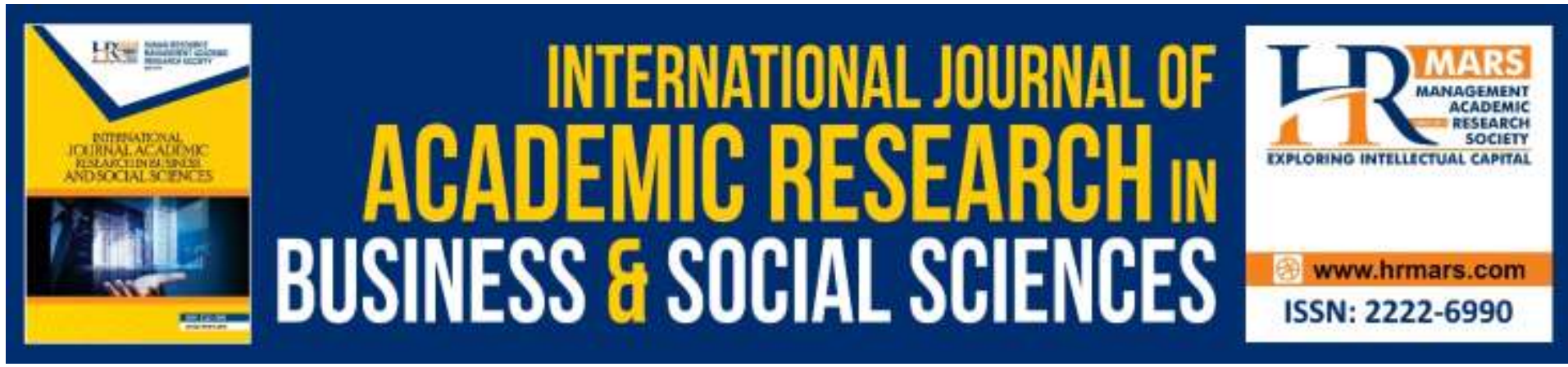

\title{
Inclusive Development for B40 Households Group: Malaysian Reality in Achieving Developed Nation Status by 2025
}

\author{
Radieah Mohd Nor \\ Centre for Global Sustainability Studies (CGSS), Universiti Sains Malaysia, Malaysia \\ Fellow at Centre for Islamic Development Management (ISDEV), Universiti Sains Malaysia, \\ Malaysia \\ Email: radieah@usm.my
}

\begin{abstract}
There are too many indicators to be fulfilled by Malaysia to become a high-income developed nation by 2025. However, in these less than seven years left, it is recommended for Malaysia to focus on more critical issues such as the four foundations of happiness for human beings as stated in a hadith by Prophet Muhammad (pbuh) which can be related to the Malaysian Quality of Life Index (MQLI). These four foundations that can be related to the components and indicators (MQLI) and turned into conceptual framework to scrutinize the development achieved by Malaysia are family life, residence, public security and transportation. Content analysis based on data obtained from government reports was studied to evaluate inclusive development implemented by the government especially for households with income lower than RM3,855 or the bottom $40 \%$ also known as the B40 households. Based on researches conducted, it is apparent that there is still a lot to be done by the government to achieve the inclusive development as has been proclaimed. The four foundations that are made into the conceptual framework still require special attention by the government and the society in achieving the developed nation status.
\end{abstract}

Keywords: Developed Nation, B40 households, Inclusive Development, Malaysian Quality of Life Index (MQLI)

\section{Introduction}

The $11^{\text {th }}$ Malaysia Plan defines high-income nation as a country with per capita income of at least AS\$15,000. Based on the statistic from 2014, Malaysia's income per capita amounted to AS\$10,796 (EPU, 2015a). However, it is less meaningful to merely be a high-income nation if it is also followed by high cost of living for the people. According to Mahathir Mohamad (2013), most of high-income nations also have high rate of wage but with cost of living far lower than it is in Malaysia. This proves that high income alone means nothing if the cost of living is also high as it results in the reduced purchasing power of the people. The high cost of living has a large implication especially to the bottom $40 \%$ of the household income group also known as the B40 households. 
Malaysia aimed to become a developed nation by 2020 through a long-term development plan and policy known as Wawasan (2020). However, this aim has been extended to the year 2025 as the government found that there are still aspects not being accomplished by Malaysia at this time. Before this, Wawasan (2020) had entered the last five-year development plan phase, the $11^{\text {th }}$ Malaysia Plan (11MP) before it was expected to achieve the developed nation status by the year 2020. With its "Anchoring Growth on People" theme, the 11MP gives special attention to improve income and wellbeing of the B40 households. This effort is implemented through the first strategic thrust of the 11MP which is enhancing inclusiveness towards an equitable society. This thrust is comprised by five focus areas as the following:

(i) Uplifting the B40 households towards a middle-class society;

(ii) Empowering communities for a productive and prosperous society;

(iii) Transforming rural areas to uplift wellbeing of rural communities;

(iv) Accelerating regional growth for better geographic balance; and

(v) Enhancing Bumiputera Economic Community (BEC) opportunities to increase wealth ownership.

Compared with the race-oriented New Economic Policy (NEP), 11MP outlines a development strategy which is inclusive in nature to uplift the people's economy which is the root of the nation's socioeconomic development and prosperity. One of the reasons for this is to achieve a developed nation status, Malaysia must ensure that its people are in the high-income group with per capita income of at least AS\$15,000. This study attempted to identify whether the inclusive development planned in the first thrust of the 11MP has truly accomplished the five focus areas as outlined to ensure that the developed nation status is achieved by 2025 .

\section{Literature Review}

Inclusive development is also usually interpreted as inclusive growth. This inclusiveness means that all groups in the society such as the citizens, the government and the private bodies mutually contribute and gain equitable profits from the revenue of the country's development (Oxfam, 2013; and Jayasooria, 2016). Through inclusive development, every citizen has equitable opportunity to enjoy the growth revenue while at the same time the less fortunate can also share the opportunities created from the growth (Rauniyar and Kabur, 2009). Jayasooria (2016), Oxfam (2013), Ali (2007), Rauniyar and Kabur (2009) and Chatterjee (2005) also characterised inclusive development as a pro-poor development approach.

The term poverty was specifically mentioned in defining inclusive development by Jayasooria (2016), Chatterjee (2005) and Ifzal (2007). Samans et al. (2015) defined inclusive development or growth as growth revenue that is sustainable and continuous across a broader economic sector, creating job opportunities that are productive for the country's working age population and reducing poverty. This was also stated by Chatterjee (2005) as the development that reduces poverty and social exclusion. Ifzal (2007) defined inclusive development as the one that aims for social security for the poor and development as a measure to overcome poverty issue and to reduce income inequality. Meanwhile, without the term inclusive, Borhan (2008) stated that development in Islam is seen as comprising inclusivity by emphasizing on the aspects of economy, morality, spirituality, materialism and 
society that are to be balanced in achieving socioeconomic development aim. This includes ensuring that wealth and income distribution can be equally enjoyed by all groups in the society.

Poverty is understood as a multidimensional social problem that involves various contributing factors that also requires a multidimensional solution. Therefore, inclusive development is also comprised of social, economic, environment and even institutional dimensions according to Rauniyar and Kabur (2009). This is so that the development truly covers all aspects and provides fair benefit for all groups in the society. Kanbur and Rauniyar (2009) said that in evaluating the inclusivity level of inclusive development, a country has to consider four aspects: (i) economic growth, (ii) income distribution, (iii) dimensions other than income (such as health and education) and (iv) well-being distribution, a non-income dimension across society groups such as gender and ethnicity. According to Ifzal (2007), inclusive development requires three approaches to ensure its successful implementation: (i) environmentallyfriendly, competent and sustainable growth, (ii) equal political and economic grounds and (iii) competent and effective social security and protection system. These approaches are also contained in the Sustainable Development Goals (SDGs) that aim for zero poverty through multidimensional solutions.

A country's development and growth are frequently measured solely on the per capita gross domestic product (GDP), job opportunities, labour productivity and healthy lifespan. These conditions have no significance if they are not being enjoyed by the largest group of the people in a country especially in countering the gap in wealth distribution. Various countries have implemented inclusive development strategy to achieve free poverty agenda based on their own capacity and priorities. One of them is The Zero Hunger Project undertaken by the government of Brazil by involving various civil society organisations which has successfully liberated 28 million of its people from starvation cycle. India has successfully improved the effectiveness of healthcare system for its people through community-based inspection system involving non-government bodies. Kenya has allocated $5 \%$ of its income tax revenue to encourage women to involve in entrepreneurship activities. This program also involves a variety of training and knowledge transfer assisted by civil society groups.

Malaysia has been recording rapid economic growth since 1970s and listed as one of the most competitive countries based on the Global Competitiveness Report 2017-2018. However, this growth is considered to be pointless if the government ignores the needs of the marginalised groups. In the Malaysian context, inclusive development policy began with the introduction of the New Economic Model (NEM) that replaced the NEP and became an essential part in two five-year development plans, the 10MP and 11MP. Inclusive development is stated clearly in 11MP document as the development for all groups of people with the main focus given at uplifting the households of the B40 group. Inclusivity in the $11 \mathrm{MP}$ is planned so that there will be no Malaysian to be marginalised, for better wellbeing of the people, high-skilled human capital, green and sustainable growth, infrastructures that are capable to support economic growth, and public service that is people-oriented and highly productive (11MP, 2016). Kamal (2018) opined that the main issue to be handled by 2020 is the existence of inequitable wealth distribution as a whole regardless of ethnicity. Without denying the contributions of the NEP especially in radically reducing the percentage of the poor and the 
hardcore poor, it failed to counter this issue during its implementation. However, this weakness can be dealt with by implementing a need-based strategy (Kamal, 2018). Inclusive development is seen as a two-for-one strategy for the purpose of overcoming inequitable wealth distribution through collective national development that the NEP failed to achieve during its era (Hatta and Ali, 2013).

Now, Malaysia is in the final development phase to achieve the status of developed nation by 2020. This phase is a critical one due to its very short duration despite the various aspects to focus on. The inclusive development suggested in the $11^{\text {th }}$ Malaysia Plan (EPU, 2015a) gives special attention to these six strategic thrusts:

i. Enhancing inclusiveness towards an equitable society

ii. Improving wellbeing for all

iii. Accelerating human capital development for an advanced nation

iv. Pursuing green growth for sustainability and resilience

v. Strengthening infrastructure to support economic expansion

vi. Re-engineering economic growth for greater prosperity

This article gives special attention to the first strategic thrust which is enhancing inclusiveness towards an equitable society. This first strategic plan actually serves as the foundation for the other strategic plans. Details throughout the whole 11MP illustrate the main focus of the government in uplifting B40 households. In the first strategic plan, Malaysia worked hard to reduce the gap in income distribution. This effort was proven effective as the Gini coefficient had dropped from 0.441 in 2009 to 0.401 in 2014 . The government also aims for the Gini coefficient to drop to 0.385 in 2020 . In that period, the average income of the B40 group had increased from RM1,440 in 2009 to RM2,537 in 2014 (EPU, 2015a).

\section{Research Methodology}

The goal to achieve inclusive development by 2025 demands an all-out effort by Malaysia to make it a reality. A hadith by Prophet Muhammad (pbuh) can be the source of guidance for this effort so that minimum standard of living is attainable for all. This authentic hadith from Prophet Muhammad (pbuh) serves as the conceptual framework in this article. The hadith meant is the following:

"Four things that are the sources of happiness: a righteous wife, a spacious dwelling, a good neighbour and a comfortable mount. And four things that are the sources of misery: a bad neighbour, a bad wife, a restrictive dwelling and a bad mount." (Ibn Hibban, 1997)i

This hadith was made into the conceptual framework and then compared with Malaysian Quality of Life Index (MQLI) to observe the achievement of Malaysia from 1990 to 2010 (current statistics). This comparison is essential to enable Malaysia to see the minimum needs and direction of the people instead of opting as a whole a development plan or an existing policy of Malaysia.

The data collected was obtained through scoping review method of MQLI and official reports from government agencies. It was analysed by applying content analysis based on the 
aforementioned hadith as the conceptual framework in this study. Suggestion for actions to be taken by the government in a short period of time to achieve developed nation status was then provided.

\section{Research Findings}

Based on the research framework, there are four aspects accepted as the basis of happiness for human beings which are also present in the MQLI. These are:

(i) A righteous wife which can be interpreted as a good spouse and extended to include a happy family. In the MQLI it can be compared to the family life component.

(ii) A spacious dwelling (house) which can be interpreted as a comfortable residence. Its equivalent in the MQLI is the housing component.

(iii) A good neighbor, which can be interpreted as a harmonious neighbourhood. The good neighbour meant in the hadith can also be related with the public security component as according to al-Ghazali (1993) the concept of neighbour in Islam is defined as those who live near one's residence be it on the right, left, front, back and even top and bottom accounting up to 40 houses from every angle. According to this opinion by al-Ghazali (1993), the neighbour concept can be referred to as a village, residential area or neighbourhood that should have a concept of mutual security among the residents. As for the MQLI, the similar component is the public security component that employs the crime rate indicator for every 1,000 residents.

(iv) A comfortable mount which can be interpreted as a good transportation system. The communication and transportation component in the MQLI contains private car and motorcycle ownership indicator for every 1,000 residents and can be compared to this conceptual framework.

Briefly the conceptual framework in this study is as the following Table 1: 
Table 1: Summary of the basis of happiness conceptual framework.

\begin{tabular}{|c|c|c|}
\hline Element of the hadith & MQLI component & MQLI indicators \\
\hline \multirow[t]{4}{*}{$\begin{array}{l}\text { Righteous wife (a good } \\
\text { spouse) }\end{array}$} & \multirow{4}{*}{ Family life } & $\begin{array}{l}\text { Divorce ratio (percentage of } \\
\text { residents from the age of 18- } \\
50 \text { ) }\end{array}$ \\
\hline & & Size of households \\
\hline & & $\begin{array}{l}\text { Juvenile crimes (percentage } \\
\text { of residents from the age of } \\
10-18 \text { ) }\end{array}$ \\
\hline & & $\begin{array}{cc}\text { Average } & \begin{array}{c}\text { income of } \\
\text { households }\end{array}\end{array}$ \\
\hline \multirow[t]{3}{*}{$\begin{array}{l}\text { Spacious dwelling } \\
\text { (house) }\end{array}$} & \multirow{3}{*}{ Housing } & $\begin{array}{r}\text { Percentage of units of low- } \\
\text { cost houses compared with } \\
\text { the number of low-income } \\
\text { households }\end{array}$ \\
\hline & & $\begin{array}{r}\text { Percentage of units of houses } \\
\text { with pipe water supply }\end{array}$ \\
\hline & & $\begin{array}{r}\text { Percentage of units of houses } \\
\text { with electricity }\end{array}$ \\
\hline Good neighbour & Public safety & $\begin{array}{l}\text { Crimes (for every ‘000 } \\
\text { residents) }\end{array}$ \\
\hline \multirow[t]{3}{*}{ Comfortable mount } & \multirow{2}{*}{$\begin{array}{r}\text { Transportation } \\
\text { and } \\
\text { communication }\end{array}$} & $\begin{array}{r}\text { Private cars and motorcycles } \\
\text { (for every '000 residents) }\end{array}$ \\
\hline & & Road Development Index \\
\hline & Public security & $\begin{array}{r}\text { Road Accidents (for every } \\
\text { ‘000 vehicles) }\end{array}$ \\
\hline
\end{tabular}

\section{Research Findings}

Malaysia's accomplishment in MQLI is shown in Table 2. Overall, statistics show that the quality of life achievement in Malaysia has increased compared with when MQLI was first introduced in the year 1990. However, the components of public security, family life and environment saw a decline in this period. As befit the focus of discussion in this article, only the components of public security and family life are discussed more thoroughly as the environment component is not included in the scope of the conceptual framework. 
Table 2: The value of quality of life from 1990 to 2010 according to Malaysia's Quality of Life Indicators.

\begin{tabular}{|c|c|c|c|c|}
\hline \multirow{2}{*}{ Year } & \multicolumn{3}{|c|}{ Components } \\
\cline { 2 - 5 } & $\begin{array}{c}\text { Transportation } \\
\text { and } \\
\text { Communication }\end{array}$ & Housing & Public Security & Family Life \\
\hline 1990 & 90.6 & 79.9 & 125.2 & 94.9 \\
\hline 2000 & 100.0 & 100.0 & 100.0 & 100.0 \\
\hline 2001 & 102.3 & 102.2 & 103.0 & 100.3 \\
\hline 2002 & 103.8 & 103.4 & 105.1 & 100.4 \\
\hline 2003 & 105.4 & 103.8 & 104.5 & 101.3 \\
\hline 2004 & 107.3 & 105.9 & 103.6 & 99.0 \\
\hline 2005 & 115.2 & 108.0 & 109.0 & 97.2 \\
\hline 2006 & 108.9 & 110.8 & 105.9 & 100.0 \\
\hline 2007 & 110.9 & 108.4 & 104.9 & 99.0 \\
\hline 2008 & 113.4 & 111.7 & 107.7 & 101.0 \\
\hline 2009 & 115.9 & 113.3 & 107.8 & 100.8 \\
\hline 2010 & 120.3 & 115.7 & 110.8 & 104.6 \\
\hline
\end{tabular}

\section{Righteous wife (A good spouse)}

Table 3: Component and indicators of MQLI related to 'righteous wife'.

\begin{tabular}{|c|c|}
\hline Component & Indicator \\
\hline \multirow{4}{*}{ Family Life } & $\begin{array}{r}\text { Divorce ratio (percentage of residents from } \\
\text { the age of 18-50) }\end{array}$ \\
\hline & Size of households \\
\hline & $\begin{array}{r}\text { Juvenile crimes (percentage of residents } \\
\text { from the age of } 10-18 \text { ) }\end{array}$ \\
\hline & Average income of households \\
\hline
\end{tabular}

Women are the first educational institution for children in forming a civilized family life and society. A lot of discussions had shown the importance of women and its relationship with family life such as by Razak and Hussain (2007), Rahman et al. (2017), and Rahman et al. (2010). The building of a family institution requires the cooperation of both the father and the mother. Spiritual aspect is also an essential concept in the presented hadith as Prophet Muhammad (pbuh) used the term 'righteous' conjointly with 'wife' which illustrates the importance of family building centred on obedience to Allah in creating happiness in an individual. Moreover, this spiritual element lays the foundation for all four components of happiness as described in the hadith as it was listed as the first element, illustrating its importance over the other three components.

The conceptual framework that discusses about a good spouse is also comparable to the component of family life in MQLI. Family institution plays a significant role on the structure of a society (Rahman et al., 2017). Indicators employed to evaluate this component are divorce ratio, size of households, juvenile crimes and average income of households. In this 
component, divorce is seen as an influential indicator and affects the other ones in the family life component.

The rate of divorce is indirectly related to the ever-increasing juvenile crimes as the divorce of a pair of parents would result in negative effects on their children's psychology. As a whole, divorce rate recorded an increase from 0.13 percent in the year 2000 to 0.22 percent in 2010 (EPU, 2012). Syariah Judiciary Department Malaysia reported that as much as 38,035 couples had divorced from January to August 2015. Based on this statistic, on average 156 cases of divorce happen in one day or six cases in one hour. Divorce rate saw an increase in five years from 43,749 cases in 2011 to 53,870 cases in 2014 (Kosmo, 2015). Furthermore, a divorce also would result in decrease of a household's income as it may lead to the household's income being contributed by one person only.

This situation is becoming ever more alarming when a statistic by EPU (2015b: 2-9) shows that debtors from B40 households tend to make personal loans to support their daily expenditures. This indirectly affects their financial position. In the year 2014, the indebtedness level of households with income of RM3,000 and below is seven times their annual income (RMK11: Kertas Strategik 2: 2015:2-9).

Sufficient income of households and stable financial position indirectly contribute to the decrease in juvenile crimes rate when both parents do not need to do more than one job at a given time. This enables better supervision and attention towards their children and simultaneously reduces their exposure towards various unhealthy influences resulted from desire to look for attention and pleasure outside of their home.

\section{Spacious dwelling (a comfortable house to live in)}

Table 4: Component and indicators of MQLI related to 'comfortable residence'.

\begin{tabular}{|c|c|}
\hline Component & Indicators \\
\hline \multirow{3}{*}{ Housing } & $\begin{array}{r}\text { Percentage of units of low-cost houses } \\
\text { compared with the number of low-income } \\
\text { households }\end{array}$ \\
\hline & $\begin{array}{r}\text { Percentage of units of houses with pipe } \\
\text { water supply }\end{array}$ \\
\hline & $\begin{array}{r}\text { Percentage of units of houses with } \\
\text { electricity }\end{array}$ \\
\hline
\end{tabular}

Comfortable residence is one of the most concerned aspects in planning the development of Malaysia. According to the Report of Household Income and Basic Amenities Survey (HIES) in 2014 , about $66.1 \%$ of B40 households in the city live in their own house while the rest $30.6 \%$ in rental house. Other than that, most of the households living in the city reside in a house containing crowded number of people with an average of two person for every room. This is related to the 'size of households' indicator in the 'family life' component of the MQLI. The previous low-cost housing programme had been criticized for its failure to provide comfortable residences especially in terms of its design which provided only two small 
bedrooms without considering the number and genders of the households which in turn contributed to social implications such as incest (Pauzi, 2013; Othman and Aziz, 2004). According to a statistic, the average size of households is 4.1 in 2014 (Department of Statistics Malaysia, 2017). However, the National Housing Department has now specified the terms of building low-cost houses which include to contain at least 3 bedrooms other than safe and comfortable environment and social facilities (National Housing Department, n.d.).

A statistic from 2014 also shows that 63,662 houses sheltering 273,381 households are located in squatter settlements, with most of them in Sabah, Sarawak, Penang and Johor. The abundance of these squatter settlements households is hardly surprising as almost all states in Malaysia except Kelantan and Terengganu recorded current house prices that exceed the Housing Affordability Index which is three times the households' annual median income (EPU, 2015c). This abundance is probably a result of the increasing cost of living while the salary gained is not sufficient to accommodate the rising cost of residence. Even more unsettling is the fact that the B40 group is exposed to the probability of becoming homeless if the cost of living continues to increase to the point that their capacity to rent or to own a residence is beyond their financial capability.

To counter this problem, various low-cost housing programmes are being actively undertaken by different government agencies in fulfilling the housing needs of the B40 group by 2020 (EPU, 2015a). Unfortunately, this issue continues hand in hand with the increasing cost in the building and housing industries despite the low-cost or affordable housing classification especially in large cities. The housing also must be completed with basic amenities such as clean pipe water supply and electricity which are the main necessities of daily activities and make the house comfortable and protected in terms of cleanliness and health.

\section{Good Neighbors}

Table 5: Component and indicator of MQLI related to 'good neighbour'.

\begin{tabular}{|c|c|}
\hline Component & Indicator \\
\hline Public Security & Crimes (for every '000 residents) \\
\hline
\end{tabular}

Neighborhood is important in ensuring the wellbeing of society especially in terms of public security (Hussain et al., 2011). Good neighborhood will create security guarantee (Chong, 2007) and reduce crimes rate and index, ensuring stable politics and economic growth (Salmi, 2006). Cost of living can also contribute to the rise and fall of public security value. Even though the correlation between the two is not apparent, financial stress is capable to be a factor of crimes. In MQLI, public security is one essential component in measuring the quality of life. This index sees public security as being important in ensuring social stability and security (EPU, 2012). Compared with other components discussed in this article that have positive values, public security component presents indicators that are negative in nature. Two indicators used by MQLI to measure public security are crimes rate and road accidents rate for every 1000 vehicles in Malaysia. 
Even though public security had decreased rapidly in 2000 with 100.0 point compared with 125.2 in 1990, this component became even more positive from year to year (EPU, 2012). However, a more drastic action is required as public security is an aspect that cannot afford to be compromised. This component must be given serious attention in securing the quality of life of Malaysian society. As a result, the public can have a sense of security which in turn enables them to function at their best especially in satisfying basic needs such as strengthening their economic, social and spiritual needs as said in the hadith by Prophet Muhammad (pbuh) discussed previously in the research methodology part.

\section{Comfortable Mount}

Table 6: Components and indicators of MQLI related to 'comfortable mount'.

\begin{tabular}{|c|r|}
\hline Components & Indicators \\
\hline \multirow{2}{*}{ Transportation and Communication } & Private cars and motorcycles (for every '000 \\
& residents)
\end{tabular}

Vehicle or transportation is one of non-food basic component in deciding the national poverty line income (PLI) to evaluate minimum needs to be fulfilled by every individual. A good transportation system is also an important wellbeing indicator as contained in the words of Prophet Muhammad (pbuh) presented in the previous methodology part. According to AlMunawi, a good transportation is one that is fast, comfortable and easy to ride and ease the movement (Muhadi, 2018). Even Prophet Muhammad (pbuh) himself said that a bad or uncomfortable mount is a source of misery for human beings. Based on these words by Prophet Muhammad (pbuh), it is important for a developed country to have a good and perfect transportation system. It is for this reason that in achieving the Malaysia's goal to be a developed nation by 2020 , the national transportation system must also be reformed.

Transportation system comprises a network of roads and transportation infrastructures. However, in MQLI, the transportation component is combined with communication component. In MQLI, only two indicators are presented to measure the transportation component: ratio of private vehicles (cars and motorcycles) and road development index (EPU, 2012). The road development index involves the length and area of roads based on the number of residents (EPU, 2005). Observation on these indicators shows that transportation system focuses more on the usage of private vehicles and road infrastructures. A similar situation occurred in the plan presented in 11MP that focuses more on improving road safety (EPU, 2015c). However, for those with low income in the B40 group, public transportation system is even more important as they are exposed to the unaffordability to own a private vehicle. For this reason, to ensure successful implementation of inclusive development, a comprehensive planning for the transportation system must be undertaken involving a wider coverage and better quality of the rail system and motorized public transport.

\section{Analysis}

Prophet Muhammad (pbuh) presented four essential aspects of happiness for a human being. These four aspects are made the basis of the method to analyses development. These aspects 
are a spouse that can be related to family life, residence, a neighbor that can be related to environment security, and a mount that can be related to transportation system. The analysis on the Malaysia's aim in implementing inclusive development for B40 group to achieve developed nation status by the year 2020 had been done on these four aspects by referring to MQLI and 11MP document.

This study found that the government of Malaysia had planned to develop these four aspects and is working hard to make it work. However, more planning and effort are required to ensure each of these aspects can be accessed by B40 households if Malaysia truly aspires towards inclusive development in achieving its goal to be a developed nation by 2020 . These four aspects are interwoven with each other and depend on the economic capacity of the B40 group. If they are handled well by the government, they would also affect other indicators that are essential to achieve the status of a high-income developed nation.

A harmonious family having a comfortable house and vehicle followed by a good neighborhood is capable to result in positive atmosphere for the whole society. Besides, this situation opens the door for society members to be more open-minded and mature be it in terms of their action or mentality. A society living in a country with developed nation status should also have a world-class mentality. It would be unfortunate if the government succeeds to provide worldclass facilities or to become a developed nation but the mentality of its society is still on the same level as a third-world country.

\section{Conclusion}

There is indeed a lot of aspects to give attention to by the government in achieving highincome developed nation status by 2025 . However, at least four aspects should be given special attention by the government to successfully implement inclusive development especially for B40 households. These aspects are harmonious family life, comfortable residence, low rate of crimes and comfortable transportation.

The ability of B40 households to achieve a more comfortable standard of living would be even more meaningful if it is followed by an increase in their purchasing power. This would indirectly result in the four foundations of human wellbeing as stated in the hadith used as the conceptual framework in this article could be reached by every B40 household.

\section{Acknowledgement}

This paper is a part of a research funded by Research University Grant (1001/PCGSS/816308) awarded by Universiti Sains Malaysia. The writers wish to express their heartiest gratitude to all other parties who have been involved either directly or indirectly in this research.

\section{References}

Al-Ghazali. (1993). Ihya Ulum al-Din, Jld 2. Karachi, Pakistan: Darul-Ishaart.

Borneo Post. (2015). 1,644 kes keganasan rumah tangga, Januari-April 2015. Borneo Post, [online] 16 Jun. Boleh didapati daripada http://www.theborneopost.com/2015/06 /16/1644-kes-keganasan-rumah-tanggajanuari-april-2015/ [Dilayari pada 12 Oktober 2016].

Chong, S. T. (2007) It Takes A Village to Raise A Child: Building Social Capital in Safe and 
Cohesive Neighbourhood, e-Bangi : Journal of Social Sciences and Humanities, 2(2), 1 12.

EPU, Unit Perancang Ekonomi. 2005. Kualiti Hidup Malaysia 2004. Putrajaya: Unit Perancang Ekonomi, Jabatan Perdana Menteri Malaysia.

EPU, Unit Perancang Ekonomi. 2012. Kualiti Hidup Malaysia 2011. Putrajaya: Unit Perancang Ekonomi, Jabatan Perdana Menteri Malaysia.

EPU, Unit Perancang Ekonomi. 2015a. Rancangan Malaysia Kesebelas. Putrajaya: Unit Perancang Ekonomi, Jabatan Perdana Menteri Malaysia.

EPU, Unit Perancang Ekonomi. 2015b. Rancangan Malaysia Kesebelas: Kertas Strategik 2. Meningkatkan Taraf Isi Rumah B40 Kearah Masyarakat Kelas Menengah. Putrajaya: Unit Perancang Ekonomi, Jabatan Perdana Menteri Malaysia.

EPU, Unit Perancang Ekonomi. (2015c). Rancangan Malaysia Kesebelas: Kertas Strategik 6. Menyediakan Perumahan Mampu Milik yang Mencukupi dan Berkualiti. Putrajaya: Unit Perancang Ekonomi, Jabatan Perdana Menteri Malaysia.

Hussain, M. Y., Samsurijan, M. S., Ishak, S. and Awang, A. H. (2011) Hubungan Kejiranan Dalam Membentuk Kesejahteraan Hidup Masyarakat 'Kampung Bandar': Kes Kampung Berjaya dan Kampung Mempelam, Alor Setar, Malaysia, Malaysian Journal of Society and Space, $7(3), 36-44$.

Hibban, I. (1997). Sahih Ibn Hibban, Jld. 9. Berut: Muasasah al-Risalah.

Jabatan Perumahan Negara (n. d.) Skim Pinjaman Perumahan Untuk Golongan Berpendapatan Rendah diakses dari

http://ehome.kpkt.gov.my/index.php/pages/view/66 pada 12 Ogos 2019.

Kosmo. (2016). Kes cerai di Selangor paling tinggi. DIm. Negara, 12 Januari 2016. Diperoleh dari

http://www.kosmo.com.my/kosmo/content.asp?y=2016\&dt=0112\&pub=Kosmo \&sec =Negara\&pg=ne_01.htm

Mohamad, M. (2013). Negara Berpendapatan Tinggi. Chedet, [blog] 21 Oktober. Boleh didapati daripada <http://chedet.cc/?p=1104> [Dilayari pada 10 Oktober 2016].

Muhadi, M. S. (2018, November 7) Irsyad Al-Hadith Siri Ke-298 : Syarah Hadis Tanda Bahagia Ada Tiga, diakses daripada https://muftiwp.gov.my/ms/artikel/irsyad-al-hadith/2734irsyad-al-hadith-siri-ke-298-syarah-hadis-tanda-bahagia-ada-tiga pada 15 Ogos 2019

Pauzi, H. M. (2013) Konsistensi Matlamat Dan Objektif Program Perumahan Kos Rendah Dengan Keperluan Perumahan Kumpulan Sasar, The Malaysian Journal of Social Administration, 9 (1), 87-110.

Othman, A. and Aziz, A. (2004) Fenomena Sumbang Mahram di Kalangan Masyarakat Islam di Malaysia. Dalam: Seminar Antarabangsa Nilai dalam Komuniti Pasca Modenisme (SIVIC 2004), 4-6 September 2004, Hotel City Bayview Langkawi. (Unpublished)

Rahman, A. H. A., Ahmad, W. I. W. and Ismail, Z. (2010) Peranan Wanita dalam Pembangunan Keluarga dari Perspektif Fi Zilal AlQuran, Journal of Governance and Development, 6(1), $14-21$.

Rahman, S. N. H. A., Kashim, M. I. A. M. and Pitchan, M. A. (2017) Journal of Social Sciences and Humanities, 12(3), $1-16$.

Razak, R. R. A. and Hussain, N. H. N. (2007) Peranan Institusi Keluarga Dalam Penjanaan Bangsa Bertamadun, Jurnal Kemanusiaan, 5(1), 73 - 82.

Salmi, V. (2006) The Association Between Social Capital And Juvenile Crime: The Role Of Individual And Structural Factors, European Journal of Criminology, 3 (2), 123-148. 
INTERNATIONAL JOURNAL OF ACADEMIC RESEARCH IN BUSINESS AND SOCIAL SCIENCES

Vol. 9, No. 7, July, 2019, E-ISSN: 2222-6990@ 2019 HRMARS

Hadis no. 4032 daripada Sa'ad bin Abi Waqas radhiallahu 'anh, dikeluarkan oleh Ibn Hibban, dinilai sahih oleh Syu'aib al- ${ }^{\mathrm{i}}$ Arna'uth. 